\title{
CIDH saluda aprobación de la nueva Ley de Migración en Brasil
}

Washington, D.C. - La Comisión Interamericana de Derechos Humanos (CIDH) saluda la aprobación legislativa y sanción de la nueva Ley de Migración en Brasil. La CIDH insta al gobierno federal brasileño a promover un proceso abierto y transparente para la reglamentación de la ley, con la participación de la sociedad civil, respetando los principios, normas y estándares interamericanos de derechos humanos.

La nueva ley de migración incorpora al ordenamiento jurídico brasileño el repudio y la prevención de la xenofobia, el repudio de las prácticas de deportaciones sumarias o expulsiones colectivas, la no criminalización de la migración, la no discriminación en virtud los medios de entrada al territorio nacional, acogida humanitaria y acceso libre e igualitario a los servicios públicos, beneficios y programas sociales, diálogo social en la formulación, ejecución y evaluación de las políticas migratorias y la promoción de la participación ciudadana del migrante, la protección integral y la atención al interés superior del niño, niña o adolescente migrante, la protección de las personas brasileñas en el exterior, la promoción del reconocimiento académico y el derecho a la migración y al desarrollo humano como derechos inalienables para todas las personas.

Además, refuerza el acceso para migrantes a los derechos y las libertades civiles y los derechos sociales, culturales y económicos, incluyendo el derecho a la reunificación familiar, los derechos de asociación y de reunión para fines pacíficos y la organización sindical. En el mismo sentido, refuerza las garantías de acceso a la justicia y de asistencia legal integral gratuita en caso que sea necesaria. La nueva ley hace más accesibles los trámites de regulación migratoria, independientemente de la situación migratoria de la persona extranjera, previendo mecanismos más claros y eficientes. Asimismo, actualiza y desburocratiza los procedimientos de naturalización en general.

Otra importante innovación legislativa es la creación de dos mecanismos de 
protección: la acogida humanitaria mediante la expedición de visado o residencia específicos para situaciones no previstas anteriormente (a la luz de la experiencia brasileña con la emisión de visas de carácter humanitario a ciudadanos y ciudadanas de Haití) y la protección a las personas apátridas. Este mecanismo en la ley brasileña es resultado del compromiso asumido en la Declaración y Plan de Acción de Brasil de 2014, conmemorativa de los 30 años de la Declaración de Cartagena sobre Refugiados de 1984. Por el mecanismo creado en la legislación, la persona apátrida interesada en esa protección, tras la determinación de esa condición, recibirá permiso de residencia definitiva en Brasil y podrá optar voluntariamente por un mecanismo simplificado y rápido de naturalización brasileña.

La elaboración de la nueva ley brasileña se basó en procesos de amplia participación social desde su fase pre-legislativa. Se creó una Comisión de Expertos con la tarea de proponer un anteproyecto de ley y se realizó una Conferencia Nacional sobre Migraciones y Refugio. En la fase legislativa, muchas de las contribuciones de los expertos y de la sociedad fueron democráticamente consideradas por el proyecto de ley del Senado. La CIDH destaca que se trata de la primera reforma migratoria integral hecha en Brasil que cuenta con el voto parlamentario. Las legislaciones anteriores fueron resultado de mecanismos que suprimieron la aprobación legislativa o fueron adoptados mediante decretos-ley de gobiernos autoritarios. Para garantizar que la legislación brasileña alcance los resultados sociales declarados, la CIDH insta al Estado brasileño a seguir con un proceso de reglamentación de la ley abierto y transparente, con participación de la sociedad civil, de conformidad con los principios, normas y estándares interamericanos de derechos humanos.

La CIDH reitera que a efectos de que las políticas y leyes migratorias obedezcan a un verdadero enfoque de derechos humanos es necesario separar las funciones migratorias de las funciones de policía criminal. A pesar de esto, la CIDH valora y considera que la nueva ley brasileña representa un avance y una referencia importante para toda la región, en especial en un contexto global marcado por la adopción, por parte de diversos países, de políticas migratorias restrictivas y de mecanismos más rígidos de control contra la entrada de inmigrantes en sus territorios. 
Comunicado de prensa 78/17

16 de junio de 2017

Comisión Interamericana de Derechos Humanos

http://mailchi.mp/dist/cidh-saluda-aprobacin-de-la-nueva-ley-de-migracin-enbrasil? $e^{=690500 c 4 d c}$ 
